\title{
Analisis Pengaruh Rasio Pelarut Etanol Terhadap Kinerja Nanopartikel Silika Mesopori dari Sekam Padi sebagai Material Pengantar Obat
}

\author{
Riska Fitri Amalia, Hariyati Purwaningsih, Diah Susanti dan Vania Mitha Pratiwi \\ Departemen Teknik Material dan Metalurgi, Institut Teknologi Sepuluh Nopember (ITS) \\ e-mail: hariyati@material.its.ac.id
}

\begin{abstract}
Abstrak-Sekam padi merupakan hasil samping proses pengolahan padi, dimana dengan melakukan proses ekstraksi akan didapatkan silika dengan kemurnian yang tinggi. Selain itu silika dari sekam padi dapat dijadikan silika mesopori yang dapat digunakan sebagai material pengantar obat untuk meningkatkan disolusi dari parasetamol. Penelitian ini bertujuan untuk menganalisa kemampuan release parasetamol dalam nanopartikel silika mesopori dan menganalisa kemampuan disolusi parasetamol dalam nanopartikel silika mesopori. Penelitian ini terbagi menjadi 4 tahap yaitu sintesis silika, sintesis silika mesopori, proses enkapsulasi parasetamol ke dalam silika mesopori, dan proses kompaksi menjadi tablet. Rasio pelarut etanol divariasikan pada 1:0 $(0 \mathrm{ml}), 1: 1(1,75 \mathrm{ml})$ dan 1:2 $(3,5 \mathrm{ml})$. Berdasarkan pengujian, sampel yang memiliki kemampuan release yang lama yaitu sampel dengan rasio pelarut 1:1 dengan membutuhkan waktu 20 jam sampai tablet habis, sejalan dengan hal tersebut, hasil pengujian disolusi memiliki hasil yang optimal pada sampel dengan rasio pelarut 1:1 dengan \% disolusi sebesar $34,56 \%$.
\end{abstract}

Kata Kunci-Disolusi, Etanol, Parasetamol, Sekam Padi, Silika Mesopori

\section{PENDAHULUAN}

$\mathrm{I}^{\mathrm{s}}$ NDONESIA sebagai negara agraris merupakan negara produsen padi terbesar ketiga di dunia setelah Republik Rakyat Cina dan India. Namun, hingga saat ini hasil samping pengolahan padi serta limbahnya belum dimanfaatkan secara maksimal. Sekam merupakan hasil samping saat proses penggilingan padi dan menghasilkan limbah yang cukup banyak [1]. Salah satu potensi yang dapat dikembangkan dari sekam padi yaitu silikanya, dimana kandungannya dapat mencapai $94 \%$ dari abu sekam padi. Data diatas menggambarkan bahwa sekam padi mempunyai potensi untuk dimanfaatkan sebagai sumber silika, sehingga nilai ekonomis dari residu pertanian ini dapat ditingkatkan.

Silika pada umumnya sering digunakan dalam dunia industri kaca dan gelas sebagai bahan utama. Seiring dengan perkembangan zaman silika mulai direkayasa menjadi nanopartikel silika mesopori (MSNs). Salah satu bentuk MSNs yang pertama adalah Mobile Composition of Matter No. 41 (MCM-41), yang memiliki susunan mesopori hexagonal 2D, yang dapat digunakan untuk berbagai aplikasi dalam bidang biosensor, drug delivery dan bidang lainnya yang membutuhkan luas permukaan material yang tinggi serta berpori [2]. Pada sintesis MSNs bahan utama yang digunakan sebagai sumber silika adalah sekam padi, yang memiliki

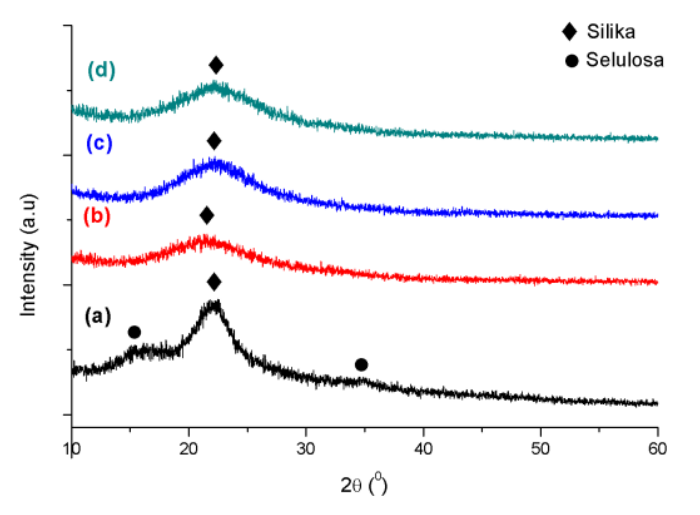

Gambar 1. Difraktogram XRD (a) Sekam Padi, (b)Abu Sekam Padi, (c)Silika hasil ekstraksi, (d)Silika Mesopori

keunggulan dapat menurunkan biaya produksi, memperbaiki efisiensi efektivitas pengiriman obat ke tubuh dan meningkatkan nilai jual dari sekam padi.

Parasetamol atau asetaminofen adalah obat analgesik dan antiperik yang populer digunakan. Parasetamol tergolong obat yang sukar larut dalam air, kelarutannya dalam air 1:70. Suatu obat harus mem punyai kelarutan dalam air sehingga obat dapat masuk ke sistem sirkulasi [3]. Formulasi obat yang dikendalikan juga telah menjadi strategi yang semakin penting dalam pengobatan terapi. Dalam formulasi obat yang terkontrol, efek farmakologis dapat dihindari dengan melepaskan obat pada tingkat yang terkendali dengan waktu atau bisa disebut dengan disolusi [4]. Formulasi obat yang terkontrol memiliki keuntungan mengurangi frekuensi dosis dan jumlah dosis total, mengurangi efek samping, mencapai konsentrasi/respons darah yang lebih seragam dan meningkatkan terapi serta kenyamanan pasien [5].

Pada penelitian sebelumnya telah dilakukan analisa terhadap sintesis dan karakterisasi silika mesopori menggunakan template CTAB. Hasil dari pengujian BET menunjukkan bahwa luas permukaan paling tinggi dihasilkan dari sampel dengan penambahan 2\% CTAB yang memiliki luas 1291.436 $\mathrm{m}^{2}$, dengan ukuran diameter porinya sebesar $4.95764 \mathrm{~nm}$ dan volume total porinya adalah $1.601 \mathrm{cc} / \mathrm{g}$. Penelitian tersebut masih membahas tentang pembentukan silika mesopori dari sekam padi namun untuk aplikasi drug delivery dari silika mesopori sendiri masih belum diteliti. Penelitian Sandy menjelaskan bahwa mesopore nano silika memiliki luas permukaan yang besar, mempunyai karakter biocompatible 
sehingga memiliki potensi besar sebagai partikel pembawa molekul obat.

Karena parasetamol memiliki kelarutan yang rendah, maka perlu dilakukan studi lanjut mengenai pengaruh rasio pelarut etanol terhadap kemampuan disolusi parasetamol dalam nanopartikel silika mesopori. Sehingga pada penelitian ini, dianalisa pengaruh rasio pelarut etanol terhadap kemampuan release parasetamol dalam nanopartikel silika mesopori dan menganalisa kemampuan disolusi parasetamol dalam nanopartikel silika mesopori. Variabel pada penelitian ini adalah rasio jumlah pelarut etanol yang divariasikan untuk menentukan kemampuan slow release dan disolusi terbaik pada obat.

\section{METODE PENELITIAN}

\section{A. Persiapan Bahan}

Mempersiapkan sekam padi, aquades, ethanol (96\%), CTAB $(99,9 \%), \mathrm{HCl}(37 \%), \mathrm{NaOH}$, asam asetat, asam nitrat (65\%), methanol (100\%) dan parasetamol (99\%).

\section{B. Ekstraksi Silika dari Sekam Padi}

Ekstraksi silika dari sekam padi dilakukan dengan mencampurkan 80 gram sekam padi dengan $600 \mathrm{ml}$ larutan $\mathrm{HNO}_{3} 2 \mathrm{M}$ pada gelas beaker lalu memanaskannya selama $2 \mathrm{jam}$ pada temperatur $90^{\circ} \mathrm{C}$. Setelah itu sekam padi dicuci menggunakan aquades hingga $\mathrm{pH}$ 7. Sekam padi yang telah dicuci selanjutnya dimasukkan ke dalam crucible furnace dan dibakar dalam muffle furnace selama 6 jam pada temperatur $600^{\circ} \mathrm{C}$. Hasil dari pembakaran tersebut berupa abu sekam padiatau rice husk ash (RHA). Abu sekam padi selanjutnya ditimbang sebanyak 6 gram dan dicampur dengan larutan 100 $\mathrm{ml} \mathrm{NaOH} 2 \mathrm{M}$ kemudian diaduk selama 2 jam pada temperature $90^{\circ} \mathrm{C}$. Hasil pengadukan kemudian disaring menggunakan kertas saring untuk dipisahkan dengan residu yang ada, atau agar mendapatkan larutan $\mathrm{Na}_{2} \mathrm{SiO}_{3}$. Kemudian larutan tersebut dititrasi dengan $\mathrm{HCl} 2 \mathrm{M}$ hingga $\mathrm{pH} 7$ dengan penambahan akuades untuk mengencerkan gel yang terbentuk. Hasil titrasi didiamkan selama 30 menit pada temperatur kamar kemudian larutan disaring dan dicuci menggunakan aquades. Gel kemudian dimasukkan kedalam crucible furnace dan dikeringkan dalam muffle furnace selama 6 jam pada temperatur $100^{\circ} \mathrm{C}$. $\mathrm{SiO}_{2}$ yang dihasilkan kemudian dikeluarkan lalu dihaluskan hingga menjadi serbuk.

\section{Sintesis Nanopartikel Silika Mesopori (MSNs)}

Proses sintesis mesoporous silica nanoparticles (MSNs) ialah dengan menggunakan bahan utama silika hasil ekstraksi dari sekam padi, dan juga memerlukan bahan lainnya seperti $\mathrm{NaOH}, \mathrm{CH}_{3} \mathrm{COOH}, \mathrm{CTAB}$, etanol dan aquades. Pertama yang dilakukan adalah mencampurkan 6 gram $\mathrm{SiO} 2$ dan 8 gram $\mathrm{NaOH}$ ke dalam $100 \mathrm{ml}$ aquades dalam erlenmeyer. Kemudian dipanaskan dengan oil bath pada temperatur $80^{\circ} \mathrm{C}$ selama 24 jam untuk mendapatkan natrium silikat $\left(\mathrm{Na}_{2} \mathrm{SiO}_{3}\right)$. CTAB dengan konsentrasi $2 \%$ dilarutkan kedalam aquades kemudian di aduk selama 30 menit pada temperatur ruangan. Setelah itu, natrium silikat dituang ke dalam gelas beaker dan larutan
CTAB ditambahkan secara perlahan - lahan menggunakan pipet dalam kondisi diaduk. Larutan $\mathrm{Na}_{2} \mathrm{SiO}_{3}-\mathrm{CTAB}$ diaduk selama 30 menit agar larutan menjadi homogen. Setelah itu larutan $\mathrm{Na}_{2} \mathrm{SiO}_{3}$-CTAB ditambahkan $\mathrm{CH}_{3} \mathrm{COOH} 5 \mathrm{M}$ hingga $\mathrm{pH} 10$ dan stirring selama 6 jam pada temperatur ruangan. Selanjutnya sol gel yang diperoleh diberi perlakuan hidrothermal dan di aging selama 24 jam dengan $\mathrm{pH}$ tetap dijaga 10. Sol gel kemudian disaring menggunakan kertas saring dan dicuci menggunakan aquades minimal 10 kali. Untuk menghilangkan CTAB dilakukan reflux dengan larutan $100 \mathrm{ml}$ methanol 99\% dan penambahan $9 \mathrm{ml} \mathrm{HCl} \mathrm{37 \%}$. Proses reflux dilakukan selama 12 jam. Setelah itu dilakukan pemisahan endapan menggunakan mesin centrifuge selama 30 menit. Hasil endapan kemudian dicuci menggunakan ethanol 99\%. Setelah di cuci dimasukkan ke dalam crucible furnace dan dikeringkan ke dalam muffle furnace pada temperatur $90^{\circ} \mathrm{C}$ selama 4 jam.

\section{Proses Enkapsulasi Parasetamol ke dalam nanopartikel silika mesopori.}

Proses enkapsulasi parasetamol ke dalam silika mesopori diawali dengan pencampuran $250 \mathrm{mg}$ parasetamol dan $250 \mathrm{mg}$ silika mesopori pada 3 buah gelas beaker. Gelas beaker yang pertama ditambahkan dengan etanol 97\% sebesar $0 \mathrm{ml}$ (rasio 1:0) dan ditambahkan aquades sebanyak 17,5 ml. Kemudian untuk gelas beaker yang ke dua ditambahkan etanol sebanyak $1,75 \mathrm{ml}$ (rasio 1:1) dan ditambahkan aquades sebanyak 17,5 ml. Untuk gelas beaker yang ketiga ditambahkan etanol seanyak 3,5 $\mathrm{ml}$ dan ditambahkan juga aquades sebanyak $17,5 \mathrm{ml}$. Kemudian ketiga gelas beaker tersebut diaduk selama $1 \mathrm{jam}$. Setelah $1 \mathrm{jam}$, dilakukan proses penyaringan menggunakan kertas saring untuk diambil filtratnya. Kemudian filtrat dikeringkan dengan cara dimasukkan muffle furnace dengan temperatur $90^{\circ} \mathrm{C}$ selama $2 \mathrm{jam}$. Setelah itu muffle furnace dikeluarkan dan dilakukan penghalusan terhadap sampel serta dilakukan pengujian.

\section{E. Pengujian}

Pengujian dilakukan untuk mengkarakterisasi fasa, gugus fungsi, struktur, ukuran pori, kemampuan mass release tablet dengan variasi rasio pelarut ethanol dalam formulasinya, dan kemampuan disolusi. Pengujian yang dilakukan adalah XRD untuk mengetahui struktur kristal, FTIR untuk mengetahui gugus fungsi, SEM untuk mengetahui morfologi dari partikelnya, BET untuk mengetahui massa luas permukaan spesifik, ukuran diameter pori rata - rata dan volume pori total, mass release untuk mengetahui lama tablet bertahan dalam larutan simulasi lambung $(\mathrm{pH} \mathrm{1,2)}$ dan pengujian disolusi untuk mengetahui persen tablet obat yang terdisolusi dalam tubuh.

\section{HASIL DAN PEMBAHASAN}

\section{A. Hasil Uji XRD}

Gambar 1. (a) menunjukkan difraktogram pengujian XRD untuk sekam padi, terdapat puncak-puncak difraksi pada $2 \theta=16,5153^{\circ}, 22,4209^{\circ}$ dan $34,8071^{\circ}$. Selanjutnya Gambar 1 


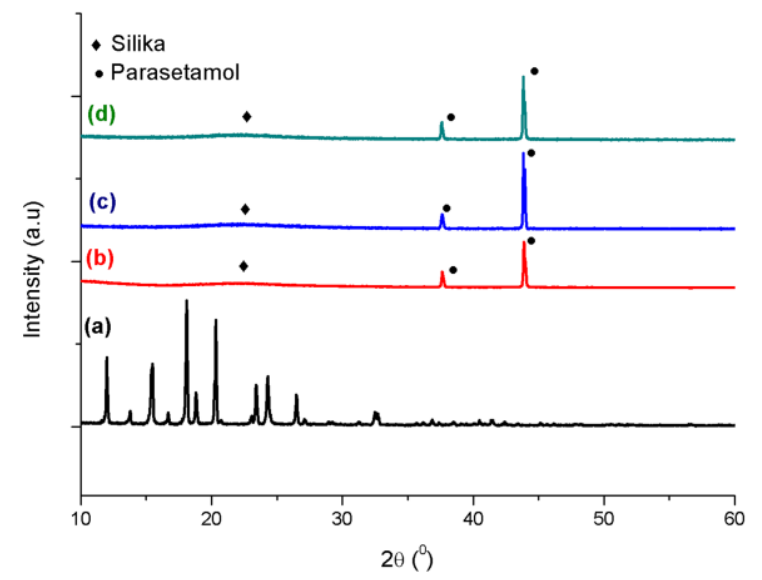

Gambar 5. Difraktogram (a) PCT, (b) Si/PCT rasio pelarut 1:0. (c) Si/PCT rasio pelarut 1:1, (d) Si/PCT rasio pelarut 1:2.

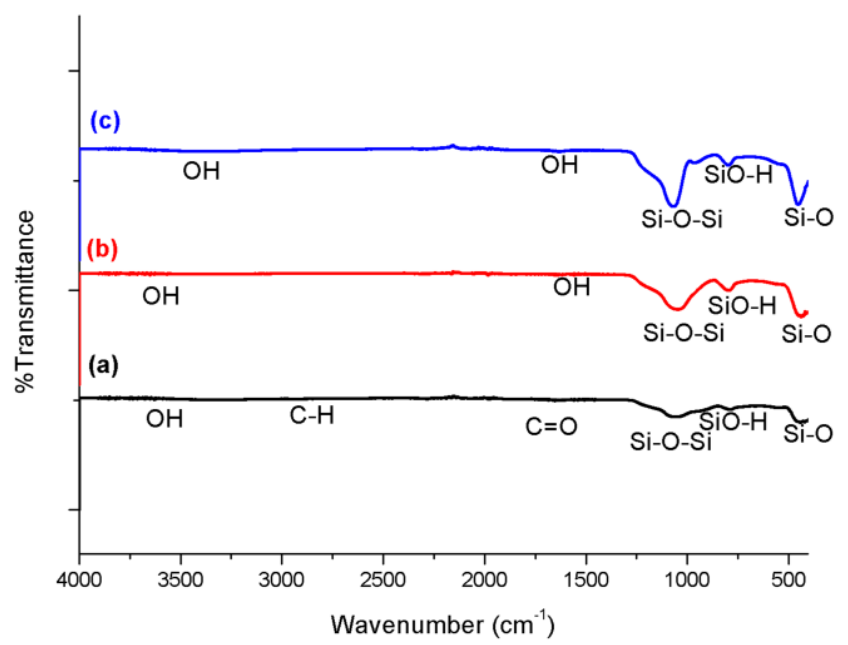

Gambar 5. Spektra Hasil Uji FTIR (a) Sekam Padi, (b) Abu Sekam Padi, (c) Silika Hasil Ekstraksi

(b) menunjukkan difraktogram XRD untuk abu sekam padi yang telah melewati hasil leaching dengan puncak difraksi di $2 \theta=21,4901^{\circ}$. Gambar 1 (c) adalah difraktogram XRD silika hasil ekstraksi dengan puncak difraksi di $2 \theta=21,8404^{\circ}$. Gambar 1 (d) adalah difraktogram dari nanopartikel silika mesopori dengan puncak difraksi di $2 \theta=22,1907^{\circ}$.

Pada puncak difraksi abu sekam padi di $2 \theta=22,4209^{\circ}$ menjadi lebih lebar dibandingkan dengan sekam padi. Perubahan lebar puncak ini dipengaruhi oleh proses pembakaran yang menyebabkan selulosa pada sekam padi terdekomposisi dan menyisakan silika amorf pada abu sekam padi. Pada proses pembakaran terjadi dekomposisi senyawa organik. Pada proses ini $\mathrm{SiO}_{2}$ berkumpul dan membentuk fasa cristobalite. Hal ini ditunjukkan oleh difraktogram XRD Abu Sekam Padi (Gambar .1 (b)) yang semakin lebar dan menjadi puncak tunggal di $2 \theta=21,4901^{\circ}$. Hal ini diperkuat lagi dengan penelitian yang melakukan pembakaran silika pada temperatur $600^{\circ} \mathrm{C}$, menghasilkan silika dengan struktur amorf dengan presentase silika 99\% [6].

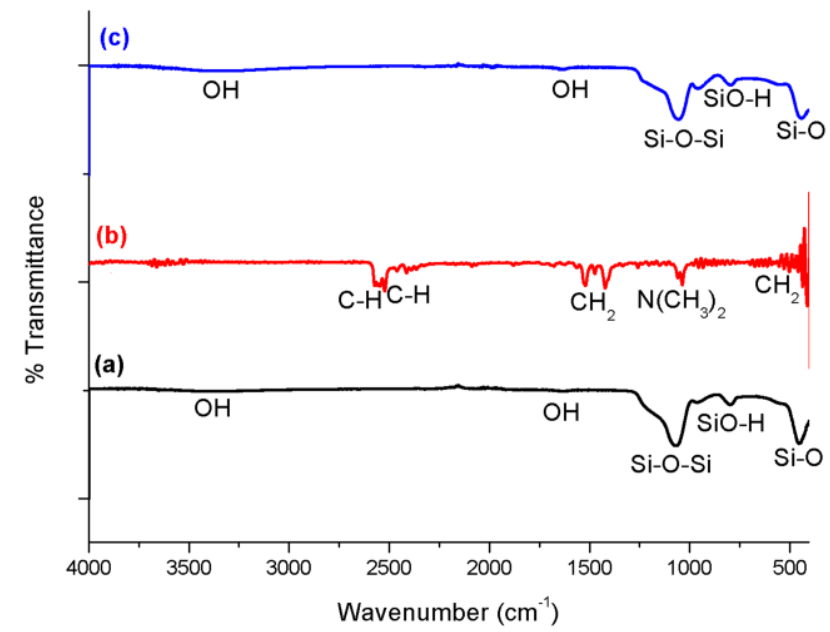

Gambar 5. Spektrum FTIR (a) Silika, (b) CTAB , (c) Silika Mesopori

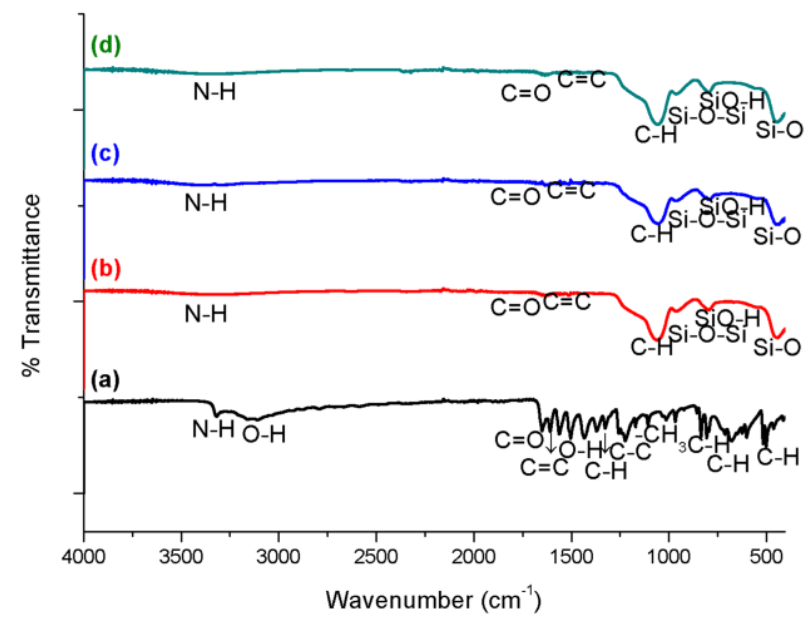

Gambar 5. Spektrum FTIR (a) PCT, (b) Si/PCT rasio pelarut 1:0. (c) Si/PCT rasio pelarut 1:1,(d) $\mathrm{Si} / \mathrm{PCT}$ rasio pelarut 1:2

Gambar 1 (d) adalah difraktogram dari nanopartikel silika mesopori dengan puncak difraksi di $2 \theta=22,1907^{\circ}$, FWHM sebesar 0,0900 dan d-spacing $=4,00275 \AA$ sesuai dengan ICDD \#01-076-0938 merupakan puncak difraksi dari crystoballite low. Puncak difraksi yang melebar menunjukkan fasa yang terbentuk silika amorf. Silika dari sekam padi memiliki sudut puncak yang melebar pada rentang $2 \theta=21-23^{\circ}$ [7]. Data ini sesuai dengan hasil karakteristik silika yang diperoleh bahwa mesoporous silika memiliki serapan intensitas dan puncak tertinggi yang terletak pada sudut $2 \theta=22,1907^{\circ}$ serta jarak antar ikatan atau d-spacing 4,00275 $\mathrm{\AA}$. Range puncak difraksi

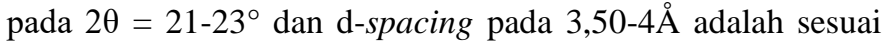
dengan identifikasi material MCM-41 [8]. Dengan memiliki puncak difraksi $2 \theta=22,1907^{\circ}$, yang mana lebih bergeser ke kanan dibandingkan dengan puncak difraksi silika hasil ekstraksi $2 \theta=21,8404^{\circ}$, dapat dikatakan bahwa material berpori (dengan penambahan CTAB 2\%) menyebabkan pergeseran puncak difraksi tetapi masih pada range d-spacing yang telah disebutkan diatas. 


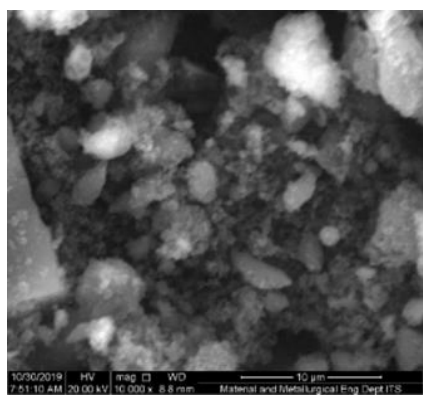

\{a)

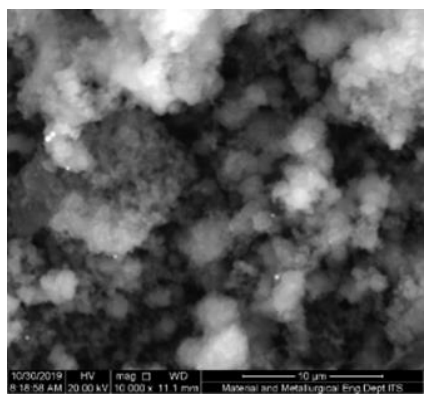

(b)

Gambar 7. Hasil Uji SEM perbesaran 10.000x (a)Silika, (b) Silika mesopori

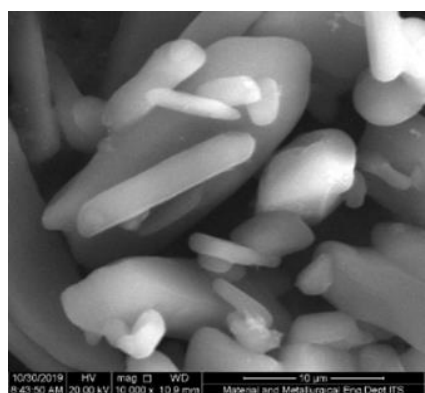

(a)

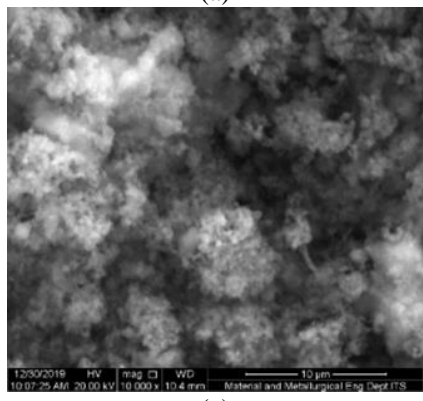

(c)

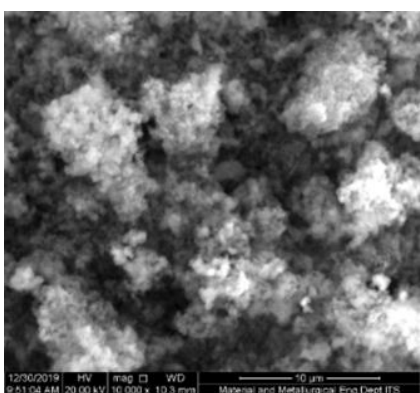

(b)

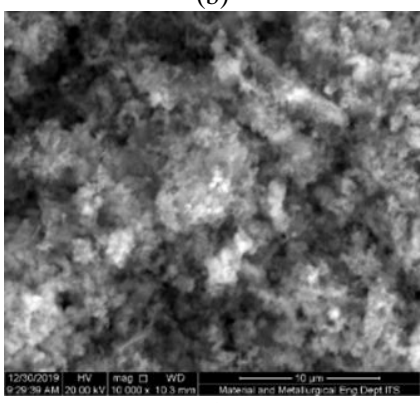

(d)
Gambar 7. Hasil Uji SEM perbesaran 10.000x (a) Parasetamol, (b) Si/PCT rasio pelarut 1:0. (c) Si/PCT rasio pelarut 1:1, (d) Si/PCT rasio pelarut 1:2

Pada Gambar 2 (a) menunjukkan difraktogram XRD untuk sampel parasetamol murni dengan 3 peak tertingginya pada $2 \theta$ sebesar $11,9803^{\circ} \mathrm{d}$-spacing $7,3847 \AA, 2 \theta=18,0954^{\circ} \mathrm{d}$-spacing $4,90241 \AA$ dan $2 \theta=20,3230^{\circ}$ d-spacing $4,36980 \AA$ berdasarkan PDF card ICDD \#00-039-1503 menunjukkan difraktogram dari parasetamol. Adapun sampel Si/PCT rasio pelarut 1:0 pada Gambar 2(b) memiliki puncak difraksi pada $21,9307^{\circ}$ dan dspacing $4,00616 \AA, 2 \theta=37,6307^{\circ} \mathrm{d}$-spacing $2,38838 \AA$ dan juga $2 \theta=43,8773^{\circ}$ d-spacing 2,06175. Pada gambar 2(c) merupakan sampel Si/PCT rasio pelarut 1:1 dengan puncak difraksi pada $22,0005^{\circ}$ dan d-spacing $4,1007 \AA, 2 \theta=43,9288^{\circ}$ dan d-spacing 2,05946 $\AA$. Sampel Si/PCT dengan rasio pelarut $1: 2$ pada gambar 2 (d) memiliki puncak difraksi pada $22,0093^{\circ}$ dan d-spacing $4,1097 \AA, 20=37,5789^{\circ}$ dan d-spacing $2,39155 \AA$ dan juga $2 \theta=43,8228^{\circ}$ dan d-spacing $2,06419 \AA$.

Untuk sampel Si/PCT rasio pelarut 1:0 1:1 dan 1:2 menunjukkan puncak difraksi pada kisaran $2 \theta=21-23^{\circ}$ untuk silika dan $2 \theta=36-38^{\circ}$ serta $2 \theta=43-45^{\circ}$ untuk Parasetamol. Terjadi penurunan puncak difraksi dengan bertambahnya rasio pelarut etanol, dan juga terjadi pertambahan d-spacing dengan bertambahnya rasio pelarut. Hal ini menujukkan bahwa semakin besar rasio pelarut etanol yang digunakan akan membuat jarak antar ikatan semakin renggang atau tinggi.

\section{B. Hasil Uji FTIR}

Pada sampel sekam padi (Gambar 3a) terdapat puncak dengan bilangan gelombang $443,20 \mathrm{~cm}^{-1}, 790,65 \mathrm{~cm}^{-1}$, dan $1031,38 \mathrm{~cm}^{-1}$ merupakan pita vibrasi tekukan Si-O, pita vibrasi peregangan asimteri $\mathrm{SiO}-\mathrm{H}$, dan pita vibrasi peregangan asimetri Si-O pada ikatan $\mathrm{Si}-\mathrm{O}-\mathrm{Si}$. Adanya gugus fungsi $\mathrm{Si}-\mathrm{O}$, $\mathrm{SiO}-\mathrm{H}$, dan Si-O-Si menunjukkan adanya unsur silika pada sekam padi. Pada gelombang $1654,50 \mathrm{~cm}^{-1}$, dan $2906,32 \mathrm{~cm}^{-1}$ merupakan pita vibrasi tekuk $\mathrm{C}=\mathrm{O}$ dan pita vibrasi regangan $\mathrm{C}$ $\mathrm{H}$. Gugus fungsi $\mathrm{C}=\mathrm{O}$ menunjukkan adanya hemiselulosa dan lignin [6] dan gugus fungsi C-H menunjukkan adanya senyawa organik yang menyusun sekam padi [9]. Sehingga adanya puncak difraksi selulosa pada hasil XRD terkonfirmasi dengan munculnya gugus fungsi $\mathrm{C}=\mathrm{O}$ dan $\mathrm{C}-\mathrm{H}$ pada hasil uji FTIR yang juga menunjukkan adanya selulosa di dalam sekam padi. Terakhir gelombang 3543,01 $\mathrm{cm}^{-1}$ merupakan pita vibrasi regangan $-\mathrm{OH}$. Gugus fungsi $-\mathrm{OH}$ dari $\mathrm{Si}-\mathrm{OH}$ meupakan vibrasi dari ikatan hidrogen. Kemunculan puncak tersebut menunjukkan adanya adsorpsi air [10].

Pada spektrum hasil uji FTIR sampel abu sekam padi (Gambar 3b) terdapat puncak dengan bilangan gelombang $440,73 \mathrm{~cm}^{-1}, 798,73 \mathrm{~cm}^{-1}, 1046,96 \mathrm{~cm}^{-1}$, dan $3441,01 \mathrm{~cm}^{-1}$ yang merupakan pita vibrasi $\mathrm{Si}-\mathrm{O}, \mathrm{SiO}-\mathrm{H}, \mathrm{Si}-\mathrm{O}-\mathrm{Si}$ dan $\mathrm{Si}-\mathrm{OH}$. Tidak terdapat spektra di kisaran $1600 \mathrm{~cm}^{-1}$ dan $2900 \mathrm{~cm}^{-1}$. Hal ini mengindikasikan bahwa proses dekomposisi telah menghilangkan unsur karbon dari sekam padi sehingga yang tersisa hanya silika amorf. Sejalan dengan hal tersebut pada hasil uji XRD juga tidak ditemukan puncak difraksi selulosa. Sehingga terdapat korelasi antara data XRD dan juga FTIR dari sekam padi hingga menjadi abu sekam padi.

Pada silika hasil ektraksi (Gambar 3 b) memiliki spektrum FTIR pada $456,90 \mathrm{~cm}^{-1}$ merupakan pita vibrasi tekukan Si-O, $798,89 \mathrm{~cm}^{-1}$ pita vibrasi peregangan simetris $\mathrm{SiO}-\mathrm{H}, 1069,78$ $\mathrm{cm}^{-1}$ pita vibrasi peregangan asimetri Si-O pada ikatan Si-O-Si, $1412,88 \mathrm{~cm}^{-1}$ pita vibrasi tekuk $\mathrm{SiO}-\mathrm{H}, 1635,64 \mathrm{~cm}^{-1}$ pita vibrasi $\mathrm{O}-\mathrm{H}$ dari air yang terabsorpsi, dan $3401,84 \mathrm{~cm}^{-1}$ pita vibrasi regangan $\mathrm{Si}-\mathrm{OH}$. Pada silika ekstraksi tidak terjadi perubahan gugus fungsi, hal ini dikarenakan pada proses sol-gel dari abu sekam padi ke silika ekstraksi tidak terdapat reaksi yang menyebabkan struktur kimia silika amorf tidak berubah

Pada Gambar 4 a terdapat grafik spektrum untuk sampel silika hasil ekstraksi dengan pita vibrasi terletak $456,90 \mathrm{~cm}^{-1}$, $798,89 \mathrm{~cm}^{-1}, 1069,78 \mathrm{~cm}^{-1}, 1412,88 \mathrm{~cm}^{-1}, 1635,64 \mathrm{~cm}^{-1}$, dan $3401,84 \mathrm{~cm}^{-1}$ yang merupakan pita vibrasi dari gugus $\mathrm{Si}-\mathrm{O}$, $\mathrm{SiO}-\mathrm{H}, \mathrm{Si}-\mathrm{O}-\mathrm{Si},-\mathrm{OH}, \mathrm{SiO}-\mathrm{H}$, dan $\mathrm{Si}-\mathrm{OH}$. Sedangkan pada Gambar 4 (b) terdapat grafik dengan pita vibrasi terletak pada $718,79 \mathrm{~cm}-1,911,15 \mathrm{~cm}-1,1461,87 \mathrm{~cm}-1$, dan $2848,39 \mathrm{~cm}-1$ yang merupakan pita vibrasi dari gugus - $\mathrm{CH} 2-, \mathrm{N}(\mathrm{CH} 3) 2,-\mathrm{CH}$. Pada silika mesopori tidak ditemukan gugus - $\mathrm{CH} 2-, \mathrm{N}(\mathrm{CH} 3) 2$, ataupun - $\mathrm{CH}-$ yang merupakan gugus fungsi dari CTAB. Adapun Gambar 4 (d) terdapat grafik spektrum dari silika mesopori dengan pita vibrasi terletak pada $444,09 \mathrm{~cm}^{-1}, 796,56$ $\mathrm{cm}^{-1}, 961,54 \mathrm{~cm}^{-1}, 1057,49 \mathrm{~cm}^{-1}, 1636,87 \mathrm{~cm}^{-1}$, dan 3335,30 $\mathrm{cm}^{-1}$ yang merupakan pita vibrasi dari gugus $\mathrm{Si}-\mathrm{O}, \mathrm{SiO}-\mathrm{H}, \mathrm{Si}-$ 


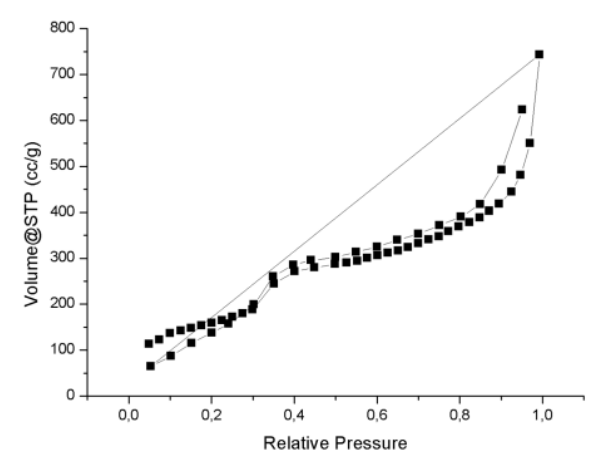

Gambar 9. Kurva nitrogen adsorption - desorption isotherms Silika dengan penambahan CTAB $2 \%$

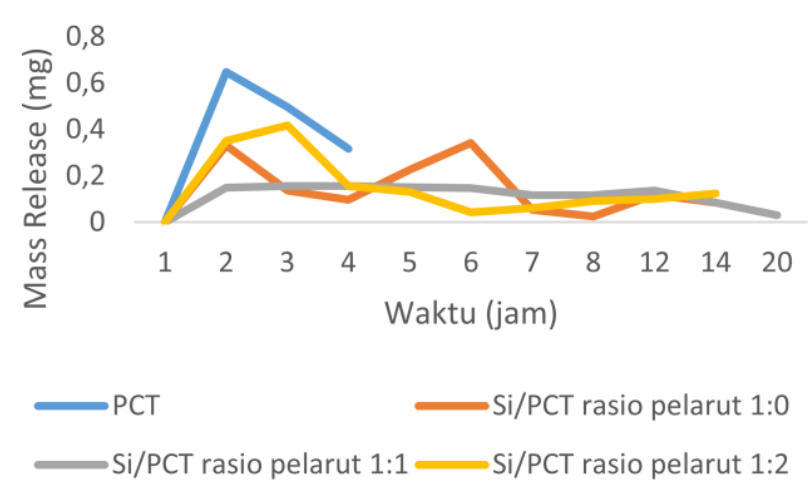

Gambar 9. Grafik pelepasan masa terhadap waktu - Pengujian pelepasan masa waktu

$\mathrm{O}-\mathrm{Si},-\mathrm{OH}, \mathrm{SiO}-\mathrm{H}$, dan $\mathrm{Si}-\mathrm{OH}$. Hal ini menunjukkan bahwa proses reflux acid methanol mampu menghilangkan $\mathrm{CTAB}$ sebagai kerangka pembentuk mesopori silika. Dengan hilangnya $\mathrm{CTAB}$ maka akan meninggalkan pori pada struktur material silika. Hasil ini sesuai dengan penelitian bahwa CTAB hilang setelah proses reflux menggunakan methanol.

Pada gambar 5 menunjukkan gugus $\mathrm{OH}$ sudah tidak mucul, yang mengindikasikan bahwa kandungan air pada sampel ini telah tidak ada, namun muncul gugus $\mathrm{NH}$ yang mengindikasikan kandungan parasetamol, gugus $\mathrm{C}-\mathrm{H}$ dan $\mathrm{C}=\mathrm{C}$ teridentifikasi yang pada pengujian FTIR silika sebelumnya tidak teridentifikasi.

\section{Hasil Uji SEM}

Adapun Gambar 6 (a) menunjukkan silika hasil ekstraksi memiliki bentuk partikel yang tidak beraturan. Terlihat masih ada partikel yang berukuran besar. Permukaannya terlihat halus dan memiliki bentuk yang padat. Sedangkan terkait bentuk partikelnya ada yang seperti serpihan-serpihan dengan ujungujung partikelnya terlihat runcing serta berbentuk balok. Gambar 6 (b) menunjukkan hasil uji SEM silika mesopori yang memiliki morfologi seperti bunga karang yang tersusun atas partikel-partikel kecil. Hal ini bersesuaian dengan hasil penelitian yang menyatakan bahwa morfologi silika mesopori menyerupai terumbu karang yang berbentuk bulat

Gambar 7 (a) menunjukkan hasil uji SEM dari sampel Parasetamol yang mempunyai bentuk kristal berupa kristal jarum. Hal ini terlihat adanya bidang yang memanjang dan
Tabel 2.

Hasil Uji BET silika mesopori

\begin{tabular}{cccc}
\hline \hline Nama Sampel & $\begin{array}{c}\text { Luas } \\
\text { Permukaan } \\
\left(\mathrm{m}^{2} / \mathrm{g}\right)\end{array}$ & $\begin{array}{c}\text { Ukuran } \\
\text { diameter pori } \\
\text { rata }- \text { rata } \\
(\mathrm{nm})\end{array}$ & $\begin{array}{c}\text { Total } \\
\text { Volume } \\
\text { pori }(\mathrm{cc} / \mathrm{g})\end{array}$ \\
\hline Silika Mesopori & 1291,436 & 4,95764 & 1,601 \\
\hline \hline
\end{tabular}

Tabel 2.

Data bobot sampel tablet

\begin{tabular}{|c|c|c|c|c|}
\hline No & Sampel & $\begin{array}{l}\text { Berat } \\
\text { (gram) }\end{array}$ & $\begin{array}{c}\text { Range simpangan } \\
5 \% \\
\end{array}$ & $\mathrm{Ke}$ \\
\hline 1 & Parasetamol & 0,6758 & & $\sqrt{ }$ \\
\hline 2 & $\begin{array}{c}\mathrm{Si} / \mathrm{PCT} \text { rasio pelarut } \\
1: 0\end{array}$ & 0,6725 & & $\sqrt{ }$ \\
\hline 3 & $\begin{array}{c}\mathrm{Si} / \mathrm{PCT} \text { rasio pelarut } \\
1: 1\end{array}$ & 0,6583 & $0,6274-0,6935$ & $\sqrt{ }$ \\
\hline 4 & $\begin{array}{c}\mathrm{Si} / \mathrm{PCT} \text { rasio pelarut } \\
1: 2\end{array}$ & 0,6394 & & $\sqrt{ }$ \\
\hline
\end{tabular}

Note $: \sqrt{ }=$ memenuhi kriteria, tidak terjadi simpangan lebih dari 5\%

meruncing menyerupai bentuk jarum [11]. Pada Gambar 7 (b) (c)(d) menunjukkan sampel parasetamol yang sudah terenkapsulasi dengan silika mesopori, terlihat pola terumbu karang yang menyelimuti parasetamol yang berbentuk jarum. Pada sampel ini, terumbu karang yang terbentuk lebih kokoh strukturnya.

\section{Hasil Uji Nitrogen Adsorbtion - Desorption Isotherm}

Hasil uji nitrogen adsorption - desorption isotherms pada sampel silika mesopori dengan penambahan CTAB $2 \%$ ditunjukkan pada Tabel 1.

Dengan didapatkannya data hasil uji seperti pada Tabel 2, sudah dapat dikategorikan bahwa silika dengan penambahan CTAB $2 \%$ akan mejadikan silika memiliki pori dengan ukuran meso(mesopori) Luas permukaan dengan penambahan CTAB $2 \%$ pada penelitian ini memiliki nilai lebih besar dibandingkan dengan luas permukaan pada penelitian sebelumnya dengan luas $464,10 \mathrm{~m}^{2} / \mathrm{g}$.

Kurva nitrogen adsorption - desorption (Gambar 8) pada sampel silika mesopori memiliki bentuk mirip dengan kurva nitrogen adsorption - desorption isotherms IUPAC tipe IV. Kurva tipe IV sesuai untuk fenomena kondensasi kapiler dan menunjukkan efek histeris, hal ini merupakan ciri - ciri khas dari padatan berpori, dan terjadi efek histeris pada $\mathrm{p} / \mathrm{po}=0,2$ 0,4 .

\section{E. Hasil Uji Sifat Fisik Tablet}

Hasil uji keseragaman bobot tablet tidak boleh lebih dari 2 tablet yang masing - masing bobotnya menyimpang dari bobot rata - ratanya lebih besar dari 5\%. Dari hasil pengujian telah dihitung massa tiap $t$ waktu sehingga di dapatkan grafik pada Gambar 9.

Sediaan lepas terkendali merupakan sediaan yang dirancang untuk memberikan aktivitas terapetik yang diperlama dengan cara pelepasan obat secara terus - menerus selama periode tertentu dalam sekali pemberian. Tujuan utama dari pengembangan sediaan lepas lambat adalah untuk mempertahankan konsentrasi zat aktif dalam darah pada 
Tabel 3.

Hasil uji disolusi

\begin{tabular}{cccccc}
\hline \hline Sampel & Abs & $\begin{array}{c}\text { Cs } \\
(\mathbf{p p m})\end{array}$ & $\begin{array}{c}\mathbf{C} \\
(\mathbf{p p m})\end{array}$ & $\begin{array}{c}\mathbf{W} \\
(\mathbf{m g})\end{array}$ & $\begin{array}{c}\text { \% } \\
\text { Disolusi }\end{array}$ \\
\hline $\begin{array}{c}\text { PCT } \\
\text { Si/PCT }\end{array}$ & 0,2082 & 3,332 & 83,3 & 74,98 & 29,98 \\
$\begin{array}{c}\text { Rasio } \\
\text { pelarut 1:0 } \\
\text { Si/PCT } \\
\text { Rasio }\end{array}$ & 0,027 & 4,32 & 108 & 97,2 & 38,88 \\
$\begin{array}{c}\text { pelarut 1:1 } \\
\text { Si/PCT } \\
\text { Rasio }\end{array}$ & 0,024 & 3,84 & 96 & 86,4 & 34,56 \\
pelarut 1:2 & 0,033 & 5,28 & 132 & 118,8 & 47,52 \\
\hline \hline
\end{tabular}

konsentrasi efektif. Dengan konsep obat yang lepas secara lambat dapat mengurangi frekuensi doses atau untuk meningkatkan efektifitas dari aktifitas obat.

Pada menit - menit awal jumlah obat yang terdisolusi naik dengan cepat dikarenakan tablet mengalami disintegrasi yang diikuti dengan disolusi. Selanjutnya terjadi peningkatan yang perlahan karena obat yang belum terdisolusi tinggal sedikit. Rasio pelarut tinggi menyebabkan penetrasi air semakin cepat maka ikatan antar partikel menjadi lemah kemudian tablet pecah. Oleh sebab itu waktu untuk mass release $\mathrm{Si} / \mathrm{PCT}$ rasio pelarut 1:2 lebih cepat dibandingkan dengan rasio 1:1.

\section{F. Hasil Uji Disolusi}

Tabel 3 merupakan data hasil uji disolusi dengan menggunakann metode dayung selama 30 menit. Dari Tabel 3 terlihat bahwa parasetamol terdisolusi selama 30 menit pada semua sampel berada pada kisaran $29-48 \%$. Bila digunakan aturan Banakar kisaran ini berada pada nilai $\mathrm{Q}_{0,25}(20-50 \%)$ sehingga dapat diketahui tablet memiliki waktu 120 menit untuk sekali pemakaian.. Etanol mampu menurunkan sudut kontak dengan melemahkan ikatan antar partikel sehingga waktu hancur meningkat dan akan mudah terdisolusi. Sehingga pada data disolusi diatas dengan rasio pelarut 1:2 memiliki \%disolusi yang cukup tinggi yaitu 47,52\%

Dalam penelitian kali ini dihasilkan bahwa sampel yang paling optimal dalam kemampuan disolusi untuk slow release drug delivery dan selaras dengan mass release yaitu penggunaan rasio pelarut 1:1, meskipun dengan peningkatan kadar etanol dapat mempercepat kelarutan, namun yang kita harapkan dalam drug delivery adalah obat akan bertahan cukup lama dalam tubuh sehingga kita dapat mengurangi dosis pemakaian obat.

Namun kasus khusus untuk obat Parasetamol dalam menangani gejala gejala yang harus memiliki efek secara cepat seperti dalam meredakan sakit kepala, nyeri haid, sakit gigi adalah kurang tepat apabila menggunakan metode slow release. Metode yang tepat untuk parasetamol atau obat - obat yang cara kerjanya bukan pencegahan adalah obat konvensional. Dimana obat akan release secara cepat dan \%disolusinya juga tinggi. Untuk obat yang tepat apabila diterapkan metode slow release adalah obat - obat seperti anti kanker yang penggunaanya secara continue dan memiliki t paruh waktu yang cukup panjang. Dalam penelitian ini dapat dibuktikan bahwa silika mesopori dalam fungsinya sebagai material pengantar obat (drug delivery) adalah efektif dibuktikan dengan penambahan silika mass release obat dalam jangka waktu yang panjang dan terkontrol.

\section{KESIMPULAN}

Berdasarkan hasil penelitian dan pembahasan yang telah dilakukan dapat diambil kesimpulan bahwa pengaruh rasio pelarut etanol pada tablet yang dienkapsulasi oleh silika mesopori menunjukkan tingkat mass release yang semakin panjang dibuktikan dengan lamanya tablet itu hancur. Berdasarkan data yang didapatkan kemampuan release terkontrol terbaik terdapat pada sampel dengan rasio pelarut 1:1 dengan waktu habis selama 20 jam. Hal ini menunjukkan bahwa silika mesopori memiliki kemampuan yang efektif sebagai material pengantar obat. Selaras dengan hal tersebut kemampuan disolusi untuk tablet yang dienkapsulasi oleh silika memiliki hasil optimal pada sampel dengan rasio pelarut 1:1 dengan \% disolusi sebesar 34,56\% selama 30 menit.

\section{DAFTAR PUSTAKA}

[1] A. A. M. Daifullah, B. S. Girgis, and H. M. H. Gad, "Utilization of agroresidues (rice husk) in small waste water treatment plans," Mater. Lett., vol. 57, no. 11, pp. 1723-1731, 2003.

[2] F. Tang, L. Li, and D. Chen, "Mesoporous silica nanoparticles: synthesis, biocompatibility and drug delivery," Adv. Mater., vol. 24, no. 12, pp. 1504-1534, 2012.

[3] D. Ramadon and A. MUN'IM, "Pemanfaatan nanoteknologi dalam sistem penghantaran obat baru untuk produk bahan alam," J. Ilmu Kefarmasian Indones., vol. 14, no. 2, pp. 118-127, 2017.

[4] S. Y. Tan, C. Y. Ang, P. Li, Q. M. Yap, and Y. Zhao, "Drug encapsulation and release by mesoporous silica nanoparticles: the effect of surface functional groups," Chem. Eur. J., vol. 20, no. 36, pp. 11276-11282, 2014.

[5] B. S. Luh, Rice, Volume 2: Utilization, vol. 2. Springer Science \& Business Media, 1991.

[6] A. Chandra, Y. I. P. Miryanti, L. B. Widjaja, and A. Pramudita, "Isolasi dan karakterisasi silika dari sekam padi," 2012.

[7] Y. Ervianto, "Analisa Pengaruh Konsentrasi Cetyltrimethyl Ammonium Bromide Sebagai Template Terhadap Pembentukan Silika Mesopori MCM-41 Dari Sekam Padi," Institut Teknologi Sepuluh Nopember, 2018.

[8] S. B. McCullen et al., "A new family of mesoporous molecular sieves," in Access in Nanoporous Materials, Springer, 2002, pp. 1-11.

[9] C. T. Kresge and W. J. Roth, "The discovery of mesoporous molecular sieves from the twenty year perspective," Chem. Soc. Rev., vol. 42, no. 9, pp. 3663-3670, 2013.

[10] P. Yang, S. Gai, and J. Lin, "Functionalized mesoporous silica materials for controlled drug delivery," Chem. Soc. Rev., vol. 41, no. 9, pp. 3679$3698,2012$.

[11] P. V. Haji, Son Helmi. Puwaningsih H, Susanti D, "Analisa Pengaruh Konsentrasi CTAB Terhadap Disolusi Rata-Rata Piroxicam pada Nanopartikel Silika Mesopori MCM-41," Institut Teknologi Sepuluh Nopember Surabaya, 2019. 